\title{
Exploring the Predictors of Student Satisfaction: A Case of Undergraduate Business School in Kingdom of Saudi Arabia
}

\author{
Zafrul Allam ${ }^{1, *}$, Azam Malik ${ }^{2}$ \\ ${ }^{1}$ Department of Management and Marketing, College of Business Administration, University of Bahrain, Kingdom of Bahrain \\ ${ }^{2}$ Department of Human Resource Management, Prince Sattam Bin Abdulaziz University, Kingdom of Saudi Arabia
}

Received July 1, 2020; Revised September 16, 2020; Accepted September 29, 2020

\section{Cite This Paper in the following Citation Styles}

(a): [1] Zafrul Allam, Azam Malik, "Exploring the Predictors of Student Satisfaction: A Case of Undergraduate Business School in Kingdom of Saudi Arabia," Universal Journal of Educational Research, Vol. 8, No. 11B, pp. 5760 - 5767, 2020. DOI: 10.13189/ujer.2020.082210.

(b): Zafrul Allam, Azam Malik (2020). Exploring the Predictors of Student Satisfaction: A Case of Undergraduate Business School in Kingdom of Saudi Arabia. Universal Journal of Educational Research, 8(11B), 5760 - 5767. DOI: 10.13189/ujer.2020.082210.

Copyright $(2020$ by authors, all rights reserved. Authors agree that this article remains permanently open access under the terms of the Creative Commons Attribution License 4.0 International License

\begin{abstract}
Students have their own connotations related to satisfaction because their perception influences the performance which will provide opportunities to them to get the better quality of life in later stages. The present study planned to ascertain the relationships between infrastructure, campus life, admin./staff support and faculty with academic support among business students. The investigation was designed to identify predictor(s) of student satisfaction. A total of 147 students were included in the study which has been selected randomly from the business college of Prince Sattam Bin Abdulaziz University in the Kingdom of Saudi Arabia. The student satisfaction scale was used to gather information. The data have been analyzed by means of both descriptive and inferential statistics. The result of the investigation revealed that (i) all the factors of student satisfaction had positive and significant relationships with each (ii) faculty, infrastructure and campus life were emerged as most potent predictors of students' satisfaction with academic support and (iii) majority of the students showed the moderate level of satisfaction. The significance and limitation of this investigation are also presented, which will shed the light of hope of other investigators to go ahead with similar kinds of investigation with different methodologies. Further, it is suggested in this investigation that contemporary changes in the higher education systems and varying levels of student satisfaction will surely attract the
\end{abstract}

employer to employ the talented or competent students to enhance the profits of the institutions.

Keywords Saudi Arabia, Faculty, Infrastructure, Campus Life

\section{Introduction}

Now-a-days higher education institutions are recognized as essential service sectors where the most important work is done by keeping in mind the need and expectation of customers to get satisfied, so in such institutions, customers are considered here as students. The higher educations are considered as the producer of well-equipped mind for the purpose of development and growth of the nation and society. Indeed, it is essential by knowing the importance of higher education and its customer, so, these higher education institutions must take students as a serious customer. The Kingdom is also striving hard to provide satisfaction to the subtends by opening various new universities with varied courses to produce competent human resources that will be used in profit making country in the future. Also, government established National Commission for Academic Accreditation and Assessment (NCAAA) in 2004 with an aim to create international 
standards in all higher education institutions in terms of qualities [1]. Furthermore, NCAAA started National Qualifications Framework for Higher Education in the Kingdom to link with the requirements of market and be on par with other developed international higher educations in terms of excellence. The NCAAA is acting as a policy making and planning in the higher education with Ministry of Higher Education rules and regulations to uplift the quality to push ahead with others [2-4]. However, satisfaction of students depends on contributions of NQF and NCAAA and they are working regularly very hard towards the quality to bolster the market by providing competent human resources.

Although, [5] stressed that the rapid expansion of the academic institutions and substantial increases in the cost of education in colleges forced the people to think differently to provide satisfaction to the students for the purpose of survival in a globally competitive era. Also, on the globe, the higher education institutions sought student's opinion or feedback about the varied degree of experiences in relation to their academic life, infrastructure, faculty, campus life and admin./staff support and other variables related to student satisfaction with the help of surveys, questionnaires or words-of-mouth.

Although, satisfaction as the function of expectations and getting experience with the product or service [6-8] and henceforth, human beings will be more inclined to get the services again and again due to their satisfaction [9]. However, $[9,10]$ conceptualized student satisfaction in terms of the students' attitude after the academic experience. Though, there are plenty of factors that contribute student satisfaction most importantly financially viable for students, academic and social needs [11]. Whereas, [12] opined student satisfaction as "generally accepted as a short-term attitude resulting from an evaluation of a student's educational experience". Another investigator, [13] conceptualized satisfaction "as the results when actual performance meets or exceeds the student's expectations". In this competitive era, satisfaction is a key factor for the purpose of growth and development in almost all areas of spheres business continuity.

As [14] pointed out that student satisfaction is seen in terms of words-of-mouth, who recommend to friends and others to join the university. Also, $[10,15]$ have similar opinions. It is noted that image or brand has a greater impact on retaining the existing students and attracting potential students [16]. However, [17] observed that facilities related to university attracted the students to join. It is essential that all the employees of the university either high contact or low contact employees must adhere to the principle of quality customer services to provide total student satisfaction $[18,19,20]$.

\section{Review of Literature}

Numerous previous researchers conducted research on satisfaction especially among students and estimated that various factors are influencing the satisfaction level of the students to create the image of higher education institutions [4,21-29]. Albeit, they all concluded that student satisfaction is an essential pillar for the growth and development of the nation and society and providing employability.

However, [20] conducted a study among male students of King Fahd University of Petroleum and Minerals, K.S.A., and reported that classrooms, layout, the overall cleanliness, appearance of buildings and grounds, physical environment and lighting play a significant role in providing students satisfaction.

Dissatisfactions among students observed because of larger class size [30]. The quality of faculty members and their reputation \& relationship with students have a greater influence on the reputation of the university that leads to providing satisfaction among students [14,31].

Although, [32] suggested that numerous factors influencing student satisfaction with academic student satisfaction at Asia-Pacific International University and Universitas Advent Indonesia. They revealed that working together as a team, problem-solving skills, developing the ability to plan, communication skills, course content are the factors contributing to student satisfaction. However, [33] opined that faculty knowledge, course content, materials to support students in teaching and teaching methodology are the factors associated with student satisfaction. [34] suggested that course content, faculty, the use of effective learning tools course performance scores are the factors which are affecting student satisfaction.

The scale which are using in this investigation indicates that facilities of the institutions, course content which provides the theoretical and practical knowledge, creating conducive relationship inside \& outside, supporting staff and faculty whom they learned the ethics, value etc. Towards the alignment of the satisfaction among students, the below table can be seen as key factors pertaining to satisfaction explored by selected different authors in various countries to promote quality efficiency in the academic institutions. 
Table 1. Key factors pertaining to student satisfaction

\begin{tabular}{|c|c|c|}
\hline Researcher(s) & Key factors & Country \\
\hline$[35]$ & Faculty, advising staff, classes & $\begin{array}{c}\text { United Sates } \\
\text { of America }\end{array}$ \\
\hline [36] & $\begin{array}{l}\text { Infrastructure, faculty, } \\
\text { curriculum, }\end{array}$ & $\begin{array}{c}\text { United } \\
\text { Kingdom }\end{array}$ \\
\hline [37] & $\begin{array}{l}\text { Faculty, infrastructure, course, } \\
\text { quality and availability of } \\
\text { resources }\end{array}$ & $\begin{array}{l}\text { United Arab } \\
\text { Emirates }\end{array}$ \\
\hline$[38]$ & $\begin{array}{c}\text { Social conditions, faculty and } \\
\text { educational facilities }\end{array}$ & Poland \\
\hline [39] & $\begin{array}{c}\text { Infrastructure, social } \\
\text { networking }\end{array}$ & $\begin{array}{r}\text { Kingdom of } \\
\text { Saudi Arabia }\end{array}$ \\
\hline [25] & $\begin{array}{c}\text { Loyalty, management strategy, } \\
\text { global education, international } \\
\text { students, motivation, retention, } \\
\text { management. }\end{array}$ & $\begin{array}{l}\text { United Sates } \\
\text { of America }\end{array}$ \\
\hline [7] & $\begin{array}{l}\text { Infrastructure, faculty, } \\
\text { reputation, image, }\end{array}$ & Iraq \\
\hline [21] & $\begin{array}{c}\text { Infrastructure, quality of } \\
\text { teaching, } \\
\text { Faculty, admin./staff support }\end{array}$ & India \\
\hline [40] & $\begin{array}{l}\text { Resources, management, course } \\
\text { curriculum }\end{array}$ & Turkey \\
\hline [31] & $\begin{array}{c}\text { Faculty, friendly atmospheres, } \\
\text { scientific activities; social } \\
\text { activities, infrastructure }\end{array}$ & Iraq \\
\hline [34] & $\begin{array}{c}\text { Curriculum, communication, } \\
\text { problem solving skills, team } \\
\text { member }\end{array}$ & $\begin{array}{l}\text { Thailand and } \\
\text { Indonesia }\end{array}$ \\
\hline [41] & $\begin{array}{c}\text { Infrastructure, quality of } \\
\text { services }\end{array}$ & Indonesia \\
\hline [42] & $\begin{array}{c}\text { Lecturer competence, lecturing } \\
\text { behavior }\end{array}$ & Sri Lanka \\
\hline
\end{tabular}

\section{Objectives of the Study}

The current investigation is an attempt to find out the effect of infrastructure, campus life, admin./staff support and faculty on academic amongst business students. The objectives are planned as:

1. To determine the relationships between infrastructure, campus life, admin./staff support and faculty with academic among business students.

2. To determine the predictors of academic with infrastructure, campus life, admin./staff support and faculty amongst business students.

3. To know the level of student satisfaction

4. To provide certain mechanism to improve the degree of satisfaction of the students

Hypothesis: in order to justify the result two null hypotheses were formulated as follow:

$\mathrm{HO}_{1}$ : There would not be significant relationship between academic and infrastructure, campus life, admin./staff support and faculty among business students.

$\mathrm{HO}_{2}$ : There would not be any predictors within infrastructure, campus life, admin./staff support on academic among business students.

\section{Research Methodology}

\section{Sample}

Sample can be considered as any diminutive number of individuals, events or objects chosen to portray the population in accordance with accepted bylaws. A flawless sample is one that is unbiased and representative of the population. Indeed, sample size is very much essential attributes to carryout empirical investigations that contribute meaningful role in quantitative and qualitative analyses of the data and to obtain scholastic conclusion emanated from available results. Taking into consideration the purpose of the investigation, a sample of 147 students was selected through convenient random sampling technique from College of Business administration, Prince Sattam Bin Abdulaziz University, Kingdom of Saudi Arabia. Only male business students participated in the study. Age categories of participant can be seen below in Table-2:

Table 2. Showing age categories of respondents

\begin{tabular}{|c|c|c|c|c|}
\hline $\begin{array}{c}\text { Age Categories } \\
\text { (Years) }\end{array}$ & Frequency & Percent & $\begin{array}{c}\text { Valid } \\
\text { Percent }\end{array}$ & $\begin{array}{c}\text { Cumulative } \\
\text { Percent }\end{array}$ \\
\hline less than 17 & 0 & 0 & 0 & 0 \\
\hline from 17-22 & 99 & 67.3 & 67.3 & 67.3 \\
\hline from 23-27 & 41 & 27.9 & 27.9 & 95.2 \\
\hline 28 and above & 7 & 4.8 & 4.8 & 100.0 \\
\hline Total & 147 & 100.0 & 100.0 & \\
\hline
\end{tabular}

Furthermore, all the respondents were informed in advance that their responses would be used for academic purposes and will never be revealed to any higher officials of the college to maintain the realm of the secrecy.

The criteria chosen to include the sample are that the students considered for this investigation are from various departments of business, different level of their study and age groups.

\section{Tools Used}

Student Satisfaction Scale developed by [43] student satisfaction scale applied in this investigation to gather the data. This scale comprises of 30 items with five dimensions namely: infrastructure, campus life, academic, admin./staff support and faculty. Each item rated on the continuum of five-point Likert scale with a weighted score of 1 to 5 (never to always). Moreover, the respondents' age and gender were also obtained with the help of biographical information blank sheet.

The author [44] conceptualized "reliability is to correctness of a measuring instrument which is necessary for the validity". The reliability of the scale was obtained by using SPSS version 16.0 on a sample size of 147 
students. It is observed that all five components alpha value appeared more than .7 which are acceptable as mentioned [45]. All the 30 items were obtained in the range of .790 to .886 , which indicates the satisfactory reliability of the data. Albeit, [46] postulated that high value of $\alpha$ indicates that all the items included in the scale are consistent in nature. However, [47] stated that construct validity is all about the appropriateness of the attributes in questionnaire. Internal consistency was measured to see the similarity of various items in the questionnaire and correlational measurement was taken into consideration by keeping in mind the design of the investigation and correlation of all the facets was calculated and found significant at.01 level (Ref-table2).

Table 3. Showing reliability of data

\begin{tabular}{|c|c|}
\hline Component & Cronbach's Alpha (a) \\
\hline Infrastructure & .790 \\
\hline Campus life & .886 \\
\hline Academic & .866 \\
\hline Admin./staff & .876 \\
\hline Faculty & .876 \\
\hline
\end{tabular}

\section{Design of the research}

The correlational research design has been instigated to determine the relationships between academic, faculty, infrastructure \& campus life. Further, it has been planned to explore the predictor variables which would be responsible for any variations in the dependent variable.

\section{Data Analyses}

Table 4. Mean, $\mathrm{SD}$ and Correlations between infrastructure, campus life, academic, admin./staff and faculty support of business students $(\mathrm{N}=147)$.

\begin{tabular}{|c|c|c|c|c|c|c|c|c|}
\hline Variables & 1 & 2 & 3 & 4 & 5 & Mean & Sd. & Rank \\
\hline Infrastructure & - & & & & & 18.61 & 6.106 & V \\
\hline Campus life & $.834^{* *}$ & - & & & & 19.71 & 6.715 & III \\
\hline Academic & $.801 * *$ & $.850 * *$ & - & & & 19.44 & 6.073 & $1 \mathrm{~V}$ \\
\hline Admin./Staff & $.808 * *$ & $.901 * *$ & $.837 * *$ & - & & 20.18 & 6.056 & II \\
\hline Faculty & $.810^{* *}$ & $.899 * *$ & $.866^{* *}$ & $.914 * *$ & - & 20.42 & 6.230 & 1 \\
\hline
\end{tabular}

**. Correlation is significant at the 0.01 level (2-tailed). 
Table 5. Model Summary of Regression analysis on academic with infrastructure, campus life, academic, admin./staff and faculty support of business students $(\mathrm{N}=147)$.

\begin{tabular}{|c|c|c|c|c|c|c|}
\hline \multirow{2}{*}{ Model } & \multirow{2}{*}{$\mathbf{R}$} & \multirow{2}{*}{$\begin{array}{c}\mathbf{R} \\
\text { Square }\end{array}$} & \multirow{2}{*}{$\begin{array}{l}\text { Adjusted R } \\
\text { Square }\end{array}$} & \multicolumn{3}{|c|}{ Change Statistics } \\
\hline & & & & R Square Change & F Change & Sig. F Change \\
\hline Faculty & $.866^{\mathrm{a}}$ & .749 & .748 & .749 & 433.388 & .000 \\
\hline Faculty, Infrastructure & $.882^{\mathrm{b}}$ & .778 & .775 & .029 & 18.835 & .000 \\
\hline $\begin{array}{c}\text { Faculty, Infrastructure, } \\
\text { Campus life }\end{array}$ & $.888^{\mathrm{c}}$ & .789 & .784 & .010 & 7.059 & .009 \\
\hline
\end{tabular}

a. Predictors: (Constant), Faculty

b. Predictors: (Constant), Faculty, Infrastructure

c. Predictors: (Constant), Faculty, Infrastructure, Campus life

Table 6. ANOVA of Multiple Regression of academic with infrastructure, campus life, admin./staff and faculty support of business students ( $\mathrm{N}=147$ ).

\begin{tabular}{|c|c|c|c|c|c|}
\hline \multicolumn{2}{|c|}{ Model } & Sum of Squares & df & Mean Square & F \\
\hline \multirow{3}{*}{1} & Regression & 4034.350 & 1 & 4034.350 & 433.388 \\
\cline { 2 - 6 } & Residual & 1349.786 & 145 & 9.309 & \\
\cline { 2 - 7 } & Total & 5384.136 & 146 & & 252.764 \\
\hline \multirow{3}{*}{2} & Regression & 4190.477 & 2 & 1495.239 & \\
\cline { 2 - 7 } & Residual & 1193.659 & 146.289 & 177.953 \\
\cline { 2 - 7 } & Total & 5384.136 & 3 & 1415.544 & \\
\end{tabular}

** Significant at .01 level.

a. Predictors: (Constant), Faculty

b. Predictors: (Constant), Faculty, Infrastructure

c. Predictors: (Constant), Faculty, Infrastructure, Campus life

d. Dependent Variable: Academic

Table 5 is describing the model summary of regression analysis on academic of business students and in the first step faculty emerged as the important predictor of academic within the independent variables. The correlation coefficient between independent and dependent variables $(\mathrm{R}=.866)$ was found significant. The calculated value of $\mathrm{R} 2=.749$ indicative of linear model as coefficient of determination of academic among business students. It expressed $74.9 \%$ variation in academic as dependent variable. The value of $\mathrm{F}$ - change $(\mathrm{F}=433.388, \mathrm{P}<.01)$ is considered as significant in the academic among business students. In the later step, infrastructure evolved as the predictor of academic within the independent variables. The correlation coefficient between academic and infrastructure along with faculty significant $(\mathrm{R}=.882)$. The observed $\mathrm{R} 2=.778$ displayed the linear relationship between academic and infrastructure. It described $77.8 \%$ variation in the academic and $\mathrm{F}$-Change $(\mathrm{F}=18.835$, $\mathrm{P}<.01)$ is found significant. In the third step, campus life appeared as the powerful predictor along with faculty and infrastructure. The coefficient between predictor and criterion variable $(\mathrm{R}=.888)$, which shows significant linear relationships. The coefficient of determination $(\mathrm{R} 2=.789)$ estimated $78.9 \%$ variation along with faculty and infrastructure, $\mathrm{F}$-change value is $(7.059, \mathrm{P}>.01)$ for academic. The $\mathrm{R}$ squared change (.010) accounted for
$1.0 \%$ variation of campus life with academic. The significant level of F-change partially rejects the planned null hypothesis $\left(\mathrm{HO}_{2}\right)$. The current investigation is also aligned with the previous studies of providing student satisfaction with varied facilities required to grow personally and professionally $[31,41,48-52]$.

It is observed from the table-6, that the calculated F-ratio for faculty $(\mathrm{F}=433.388, \mathrm{P}>.01)$, infrastructure $(\mathrm{F}=$ $252.764, \mathrm{P}>.01)$ and campus life $(\mathrm{F}=177.953, \mathrm{P}>.01)$ was appeared significant and contributed to the academic among business students. Therefore, henceforth, the planned null hypothesis $\mathrm{HO}_{2}$ was partially accepted.

Table 7. Exhibiting of the level of student satisfaction

\begin{tabular}{|c|c|c|}
\hline Level of EI & No. of Respondents & Per cent \\
\hline High & 49 & 33.34 \\
\hline Moderate & 62 & 42.18 \\
\hline Low & 36 & 24.48 \\
\hline
\end{tabular}

It is evident from the above table- 6 that the majority of the students in the B-school have a moderate level of satisfaction $(\mathrm{N}=62,42.18)$, high level of satisfaction obtained ( $\mathrm{N}=49,33.34 \%)$ and $24.48 \%$ students showed a low level of satisfaction. Earlier researchers, [37] observed a high level of student satisfaction in their study in United Arab Emirates because of several reasons. 
Notwithstanding, [53] had observed that extracurricular activities, self-confidence, general quality of teaching and careers are drivers of student satisfaction among U.S. business students. Albeit, [54] conducted a comprehensive analysis and observed that students enrolled in clinical degree and humanities were more satisfied than engineering and media studies.

\section{Conclusions}

Indeed, student satisfaction is very much essential for the purpose of growth and survivor of higher education holistically and increasing the momentum of the image/brand of the society or nation in the process of achieving sustainability. The present investigation objectives and hypotheses formulated by the investigators have been accomplished and the following conclusions were listed based on findings:

- It is observed that all the variables of student satisfaction had found positive relationship with each other.

- Faculty, infrastructure, campus life appeared as one of the most powerful predictors of academic support within the student studying in business college.

- Most of the students have a moderate level of satisfaction followed by a higher degree of satisfaction and low-level satisfaction.

\section{Limitation and Suggestion of the Investigation}

Based on the current investigation, it is crystal clear avenues for future direction towards the researches to integrate competencies and understand individual differences preferences to get the satisfaction during the entire course of undergraduate study. Moreover, present researchers advocated providing few constraints of the investigation which needs to be taken care by the other researchers who intended to pursue similar kinds of the investigation to add certain scholastic value in this contemporary knowledge of study. Furthermore, it is advisable that gender, sample size, nationality, different scale, statistical techniques, religion etc., should be taken into consideration to explore the predictors of undergraduate business student satisfaction. The findings of the current investigation will spark further to go in depth analysis of satisfaction especially undergraduate business school students by using varied research design. It is recommended that management and policy makers must give more attention to instill social, instrumental \& terminal values, education, psychological wellbeing and other institutional supports to enhance the level of satisfaction among students studying business [55-57]. Whereas, [58] suggested that institution which has positive, friendly, nice, and congenial environment is most likely to influence the level of satisfaction of students. Albeit, it is also suggested to explore qualitative study in this area of investigation to shed more light to understand student satisfaction in a concrete manner.

\section{REFERENCES}

[1] Darandari, E.Z., Al-Qahtani, S.A., Allen, I.D., Al-Yafi, W.A., Al-Sudairi, A.A., Catapang, J., "The quality assurance system for post-secondary education in Saudi Arabia: a comprehensive, developmental and unified approach". Quality in Higher Education, Vol.15, No.1, pp. 39-50,2009.

[2] Chakroun, B., "National qualification frameworks: from policy borrowing to policy learning", European Journal of Education, Vol. 45, No. 2, pp. 199-216,2010.

[3] Alfawaz, A., Hilal, K., Alghannam, Z., "Would the educational programs help in solving Saudi Arabia's employment challenges?" International Journal of Academic Research in Economics and Management Sciences, Vol. 3, No. 1, pp. 24-39,2014.

[4] Allam, Z., "Demystifying the Aspect of Quality in Higher Education: Insights from Saudi Arabia", Sage Open, Vol. 10, No. 1, pp.1-8, 2020, https://doi.org/10.1177/215824401989 9057

[5] Kotler, P., Fox, K.F.A., "Strategic Marketing for Educational Institutions", 2nd ed., Prentice-Hall, Englewood Cliffs, NJ.,1995.

[6] Demir, A., Mukhlis, M., "An evaluation of gated communities as a product: An empirical study in Sulaimaniyah, Iraq", Theoretical and Empirical Researches in Urban Management, Vol.12, No.3, pp. 63-84,2017.

[7] Budur, T., Rashid, C. A., Poturak, M., "Students perceptions on university selection, decision making process: A case study in Kurdistan Region of Iraq", International Journal of Social Sciences \& Educational Studies, Vol. 5, No. 1, pp. 133-144, 2018.

[8] Torlak, N.G., Demir, A., Budur, T., "Impact of operations management strategies on customer satisfaction and behavioral intentions at café-restaurants", International Journal of Productivity and Performance Management, Vol. ahead-of-print No. ahead-of-print, 2019, https://doi.org/10.1108/IJPPM-01-2019-0001

[9] Demir, A., "Importance of data analysis on achieving the organizational goals during the short-term strategic plan: case of service quality and students' satisfaction level at Ishik University", International Journal of Social Sciences and Educational Studies, Vol.3, No.3, pp. 110-121,2017.

[10] Elliott, K. M., Healy, M. A., "Key factors influencing student satisfaction related to recruitment and retention", Journal of Marketing for Higher Education, Vol.10, No.4, pp. 1-11,2001.

[11] Hartman, D. E., Schmidt, S. L., "Understanding student/alumni satisfaction from a consumer's perspective: The effects of institutional performance and program 
outcomes", Research in Higher Education, Vol. 36, No.2, pp.197-217,1995.

[12] Athiyaman, A., "Linking student satisfaction and service quality perceptions: the case of university education", European journal of marketing, Vol.31, No.7, pp.528-540, 1997.

[13] Szymanski, D. M., Henard, D. H., "Customer satisfaction: A meta-analysis of the empirical evidence", Journal of the Academy of Marketing Science, Vol.29, No.1, pp. 16-35, 2001.

[14] Browne, B. A., Kaldenberg, D. O., Browne, W.G., Brown, D. J., "Student as customer: Factors affecting satisfaction and assessments of institutional quality", Journal of Marketing for Higher Education, Vol. 8, No. 3, pp.1-14,1998.

[15] Abbott, M., Ali, E., "The impact of exchange rate variations and university reputation on the choice of destinations of international students in Australia and New Zealand", Journal of Economic and Social Policy, Vol.13, No.1, p. 7, 2009.

[16] James, D.L., Baldwin, G., McInnis, C., "Which University? The Factors Influencing the Choices of Prospective Undergraduates", Centre for the Study of Higher Education, Melbourne, 1999.

[17] Price, I., Matzdorf, F., Smith, L., Agahi, H., "The impact of facilities on student choice of university", Facilities, Vol.21, No.10, pp. 212-22,2003.

[18] Low, L., "Are College Students Satisfied? A National Analysis of Changing Expectations", Noel-Levitz, Iowa City, IA, cited in Banwet, D.K. and Datta, B. (2003), "Study of the effect of perceived lecture quality on post-lecture intentions", Work Study, Vol.52, No.5, pp. 234-43,2000.

[19] Gold, E., "Customer Service: A Key Unifying Force for Today's Campus, Netresults", National Association of Student Personnel Administrators, 22 January, available at: www.naspa.org/netresults, cited in Banwet, D.K. and Datta, B. (2003), "A study of the effect of perceived lecture quality on post-lecture intentions", Work Study, Vol.52, No.5, pp. 234-43,2001.

[20] Sohail, M.S., Shaikh, N.M., "Quest for excellence in business education: a study of student impressions of service quality", The International Journal of Educational Management, Vol.18, No.1, pp.58-65,2004.

[21] Paul, R., Pradhan, S., “Achieving Student Satisfaction and Student Loyalty in Higher Education: A Focus on Service Value Dimensions", Services Marketing Quarterly, Vol.40, No.3, pp. 245-268, 2019, https://doi.org/10.1080/15332969. 2019.1630177

[22] Allam, Z., "Students' perception of quality in higher education: An empirical investigation", Management Science Letters, Vol.8, No.5, pp. 437-444, 2018.DOI: $10.5267 / \mathrm{j} . \mathrm{msl} .2018 .4 .002$

[23] Shirazi, M., "Student satisfaction analysis and its factors (2014 to 2016), Education", Vol.7, No.4, pp. 71-81, 2017.DOI: $10.5923 /$ j.edu.20170704.03.

[24] Sulphey, M.M., Allam, Z., "Efficacy of Mentoring in Enhancing Academic Outcome of Business Students in KSA, The social Sciences, Vol.12, No.8, pp. 1384-1388, 2017.
[25] Alzamel, S., "Factors that Influence Student Satisfaction with International Programs in Institutions of Higher Learning: A Proposed Case Study of University of Dayton", International Journal of Global Business, Vol.7, No.1, $15-24,2014$

[26] Allam, Z., Ahmad, S., "An Empirical Study of Quality in Higher Education in Relation to Stakeholders' Perspectives", Journal of American Science, Vol. 9, No.12, pp. 387-401, 2013.

[27] Tahar, N., Mokhtar, R., Jaafar, N., Zamani, N., Sukiman, S., Ismail, Z., "Students' satisfaction on blended learning: The use of factor analysis". Paper presented at the 2013 IEEE Conference on e-Learning, e-Management and e-Services, Kuching, Malaysia (pp. 51-56), 2013. DOI: 10.1109/IC3e.2013. 6735965

[28] Helgesen, Q., Nesset, E., "What accounts for students' loyalty? Some field study evidence", International Journal of Educational Management, Vol.21, No.2, pp.126-143,2007.

[29] Kuo, Y., "Interaction, internet self-efficacy and selfregulated learning as predictors of student satisfaction in distance education courses", Doctoral dissertation, Utah State University, Logan, 2010, Retrieved from https://digitalcommons.usu.edu/cgi/viewcontent.cgi?article $=1737 \&$ context $=$ etd

[30] Coles, C., "Variability of student ratings of accounting teaching: evidence from a Scottish business school", International Journal of Management Education, Vol.2, No.2, pp.30-40,2002.

[31] Khan, N.S., Yildiz, Y., "Impact of intangible characteristics of universities on student satisfaction", Amazonia Investiga, Vol.9, No.26, pp.105-116,2020.

[32] Hutabarat, R., Hutabarat, F., Hutabarat, F., "Factor analysis of students' satisfaction with academic courses", Human Behavior Development and Society, Vol.21, No.1, pp.78-84,2020.

[33] Chyung, S. Y., Vachon, M., "An Investigation of the Profiles of Satisfying and Dissatisfying Factors in E-Learning", Performance Improvement Quarterly, Vol.18, No.2, pp.97113,2005 .

[34] Estelami, H., "An exploratory study of the drivers of student satisfaction and learning experience in hybrid-online and purely online marketing courses" Marketing Education Review, Vol.22, No.2, pp.143-156, 2012. DOI: 10.2753/MER1052-8008220204

[35] Oscar, W. D., Kara, A., Kaynak, E., "Determinants of business student satisfaction and retention in higher education: applying Herzberg's two-factor theory", International Journal of Educational Management, Vol19, No.2, pp.128-139,2005. DOI 10.1108/09513540510582426

[36] Douglas, J., Douglas, A., Barnes, B., "Measuring student satisfaction at a UK university", Quality Assurance in Education, Vol.14, No.3, pp. 251-267, 2006.DOI $10.1108 / 09684880610678568$

[37] Wilkins, S., Balakrishnan, M.S., "Assessing student satisfaction in transnational higher education", International Journal of Educational Management, Vol.27, No.2, pp.143-156, 2013. DOI 10.1108/09513541311297568 
[38] Sojkin, B., Bartkowiak, P., Skuza, A., "Determinants of higher education choices and student satisfaction: the case of Poland", Higher Education, Vol.63, No.5, pp.565-81, 2012.

[39] Alshareef, M.A., "Evaluate student satisfaction for social learning network at King Abdulaziz University", Advances in Internet of Things, Vol. 3, pp.41-44, 2013. http://dx.doi.org/10.4236/ait.2013.33006

[40] Zeliha Nurdan Baysal, Kamil Ersin Araç, "Conditions Determining Quality in Higher Education: Factors Affecting Satisfaction Levels of Prospective Teachers," Universal Journal of Educational Research, Vol. 7, No. 1, pp. 250 - 258, 2019. DOI: 10.13189/ujer.2019.070132.

[41] Lubis, H.M., “The Effect of Service Quality on Students' Satisfaction Using the Library of Senior High School 1 of Padangsidimpuan", Journal of Social Science, pp.16-20,2020.

[42] Opatha H. H. D. N. P., "Influence of Lecturers' Competence on Students' Satisfaction of Lecturing: Evidence for Mediating Role of Lecturing Behaviour," Universal Journal of Educational Research, Vol. 8, No. 4, pp. 1167 - 1179, 2020. DOI: 10.13189/ujer.2020.080406.

[43] Paul, S., Sahni, S., Ray, L., Saini, A., Das, R., Sachan, P., "Training instruments in HRD and OD" (3rd ed.), New Delhi: Tata McGraw- Hills Publishing Company Limited, pp.. 277-279, 2011.

[44] Kerlinger, F., "Foundations of Behavioral Research",3rd ed., Holt, Rinehart and Winston, New York,1986.

[45] Nunnally, J.C., "Psychometric Theory", McGraw-Hill, New York, 1978.

[46] Kumar,K., Beyerlein, M., "Construction and validation of an instruments for measuring ingratiatory behavior in organizational setting", Journal of Applied Psychology, Vol.76, No.5,pp.619-627,1991.

[47] Hinkin, T. R., "A Review of Scale Development Practices in the Study of Organizations", Journal of Management, Vol.21, No.5, pp.967-988,1995.

[48] Mochammad, A., "Sikap Mahasiswa Terhadap Fasilitas dan
Pelayanan Perpustakaan IKIP Malang" Universitas Indonesia, 2001.

[49] Veloutsou, C., Lewis, J. W., Paton, R. A., "University selection: information requirements and importance", International Journal of Educational Management, Vol.18, No.3, pp.160-171, 2004.

[50] Sinaga, D., "Perpustakaan Sekolah", Jakarta: Kreasi Media Utama, 2005.

[51] Darmono., "Manajemen dan Tata Kerja perpustakaan Sekolah". Grasindo, 2007.

[52] Hs, L., "Manajemen Perpustakaan Sekolah", Pinus Book Publisher, 2009.

[53] Letcher, D. W., Neves, J.S., "Determinants of Undergraduate Business Student Satisfaction", Research in Higher Education Journal, Vol.6, pp. 1-26,2010.

[54] Bell, A.R., Brooks, C., "What makes students satisfied? A discussion and analysis of the UK's national student survey", Journal of Further and Higher Education, Vol.42, No.8, 1118-1142, 2018. DOI: 10.1080/0309877X.2017.1349886

[55] Al Kahtani, N.S., Allam, Z., "Exploring Value Preferences among Students: An Empirical Study of Salman bin Abdulaziz University", Journal of American Science, Vol. 9, No., 12, pp. 44-53, 2013.

[56] Al Kahtani, N.S., Allam, Z., "Supportive and Defensive Communication Climate among Subordinate Staff of Salman bin Abdulaziz University: An Empirical Assessment", Life Science Journal, Vol.10, No.4, pp.502-509, 2013.

[57] Allam, Z., A scientific approach to understand role stress amongst business school teachers, Man in India, Vol. 97, No.10, pp. 183-196, 2017.http://www.serialsjournals.com/s erialjournalmanager/pdf/1500031224.pdf

[58] Montilla, J. M., "The construct validation of an instrument based on students university choice and their perceptions of professor effectiveness and academic reputation at the University of Los Andes", Graduate Theses and Dissertations, 2004. Retrieved from http://scholarcommons. usf.edu/etd/1166 